\title{
Upaya Meningkatkan Kemampuan Membaca Permulaan Siswa Kelas Satu Tunarungu Melalui Metode Struktural Analitik Sintetik
}

\author{
Andam Litasari ${ }^{1}$ \\ ${ }^{1}$ SLBN Prof. Dr. Sri Soedewi Masjchun Sofwan, S.H Jambi, Indonesia \\ Email: andamlita@gmail.com
}

\section{INFORMASI ARTIKEL}

Terkirim 14-Oktober-2021

Revisi 22-Oktober-2021

Diterima 27-Oktober-2021

Kata kunci:

Struktural Analitik Sintetik, membaca permulaan,

tunarungu

\begin{abstract}
ABSTRAK
Tujuan penelitian ini adalah mengetahui pengaruh Metode Struktural Analitik Sintetik bagi siswa kelas satu tunarungu. Metodologi yang digunakan pada penelitian ini adalah penelitian tindakan kelas dengan III siklus. Hasil penelitian ini yaitu adanya peningkatan yang signifikan, ketuntasan belajar dan hasil belajar siswa setelah menggunakan metode Struktural Analitik Sintetik pada siklus-III. Hal ini mengandung makna bahwa PTK dapat dinyatakan" berhasil". Keberhasilan ini ditunjukkan oleh indikator sebagai berikut : (a) Siswa berhasil mencapai kategori tuntas belajar (100\%), bahkan 38\% termasuk kategori " sangat tuntas". (b) Hasil belajar siswa mencapai nilai rerata 75 , melebihi kriteria yang ditetapkan yaitu rerata 70
\end{abstract}

(i) (O) This is an open access article distributed under the Creative Commons 4.0 Attribution License, This license lets others remix, tweak, and build upon your work even for commercial purposes, as long as they credit you and license their new creations under the identical terms @2018 by author and Universitas Negeri Padang.

\section{Pendahuluan}

Pembelajaran Bahasa Indonesia merupakan bagian penting untuk diajarkan pada siswa di sekolah, terutama ditingkat sekolah dasar kelas satu dan dua. Oleh sebab itu konteks pembelajaran bahasa yang berkaitan dengan membaca, merupakan kunci membuka dan memahami masuknya ilmu pengetahuan. Belajar membaca selayaknya mendapat perhatian yang lebih besar sebagai penentu berlangsungnya proses belajar, dengan kata lain membaca adalah landasan bagi seorang siswa untuk dapat menemukan ilmu-ilmu lainnya.

Membaca merupakan salah satu jenis kemampuan berbahasa tulis yang bersifat reseptif. Disebut reseptif disini seorang akan dapat memperoleh informasi, memperoleh ilmu dan pengetahuan baru. Semua yang diperoleh melalui membaca itu akan memungkinkan orang tersebut mampu mempertinggi daya pikirnya, mempertajam pandangannya dan memperluas wawasannya. Dengan demikian kegiatan membaca merupakan hal yang sangat diperlukan oleh siapapaun oleh sebab itu, pembelajaran membaca disekolah dasar mempunyai peran yang sangat penting.

Dalam Kurikulum Tingkat Satuan Pendidikan (Diknas No.20 tahun 2003) Sekolah Dasar Luar Biasa, pembelajaran Bahasa Indonesia terdiri dari empat aspek ketrampilan utama berbahasa, yakni meliputi aspek mendengarkan atau menyimak, berbicara atau menirukan, membaca dan menulis, ketrampilan membaca memiliki peran penting yang mesti dikuasai siswa, dengan mampu membaca siswa dapat memahami materi-materi pelajaran lain berikutnya.

Berdasarkan pengamatan yang penulis lakukan setiap hari di kelas satu pada siswa tunarungu di SLB N Prof.Dr. Sri Soedewi MSC SH Jambi, Sebagian besar siswa kelas satu Tunarungu belum dapat membaca dan menulis dengan baik. Dari empat orang siswa hanya dua orang siswa yang dapat 
membaca kata-kata dengan baik. Sedangkan dua orang siswa hanya dapat mengenal huruf, bila dirangkai menjadi suku kata dan kata siswa tidak dapat membaca dengan baik. Ini terlihat ketika dari tes ke depan kelas untuk membaca bacaan yang ada di papan tulis mereka belum bisa membaca dengan lancar. Contoh membaca kata " Meja "Siswa Sebagian besar belum dapat membaca dengan baik. Siswa sering melakukan kesalahan dalam membaca jika tidak dibimbing oleh guru.

Salah satu aspek kegiatan belajar yang merupakan bagian dari proses belajar mengajar adalah membaca. Ini termasuk salah satu keterampilan dari empat keterampilan berbahasa yaitu menyimak, berbicara, membaca dan menulis. Keterampilan membaca memegang peranan yang sangat penting dan harus dikuasai oleh anak, karena ini adalah dasar untuk mengikuti pelajaran lainnya dan menjadi bekal pengetahuan guna melanjutkan pendidikan ke jenjang yang lebih tinggi. oleh karena itu, seorang guru dituntut mampu membantu anak dalam mengembangkan kemampuan membaca terutama membaca permulaan. Di dalam pembelajaran membaca permulaan guru harus menggunakan model pembelajaran yang tepat bagi siswa tunarungu.

Menurut Sri Hastuti ( 1996) metode Struktural Analitik Sintetik atau dikenal dengan metode SAS adalah metode membaca permulaan yang dimulai dari membaca kalimat, kemudian kata, suku kata, huruf dan kembali ke kalimat lagi. Metode ini mula-mula kepada siswa diperkenalkan beberapa kalimat.setelah. setelah mereka dapat membacanya, salah satu kalimat diambil untuk diuraikan menjadi kata, kemudian kata diuraikan menjadi suku kata, suku kata diuraikan menjadi huruf-huruf, dan akhirnya kembali ke kalimat.

Contoh:

$$
\begin{gathered}
\text { Ayah pergi } \\
\text { Ayah : pergi } \\
\text { A : yah : per }: \text { gi } \\
\text { A }: \text { y }: \mathrm{a}: \mathrm{h}: \mathrm{p}: \mathrm{e}: \mathrm{r}: \mathrm{g}: \mathrm{i}
\end{gathered}
$$

Ayah pergi

Dengan penguraian itu siswa mengenal dan membaca huruf. Dengan pengenalan kalimat,kata, suku kata,huruf,dan kalimat siswa diharapkan dapat membaca kata-kata dan kalimat yang mengandung huruf-huruf tersebut. Kelebihan Metode SAS dimana dilihat dari sudut pandang psikologi cara mengajar membaca demikian itu adalah benar sebab anak-anak mengamati sesuatu dimulai dari pengamatan keseluruhan lebih dahulu kemudian menuju kebagian-bagian. Adapun kelebihan dari metode SAS adalah 1) dalam menggunakan metode SAS dimulai dari membaca kalimat-kalimat (seakan-akan membaca) barulah kemudian menuju perkataan-perkataan, suku kata, huruf dan akhirnya kepada kalimat lagi. 2) Membaca SAS ini sesuai dengan membaca yang sebenarnya. Sebab semua kalimat yang seakan-akan dibaca itu mempunyai pengertian. Jadi seperti halnya dalam membaca yang sebenarnya.

Selanjutnya Kelemahan Metode SAS dapat dilihat bahwa 1). Pembelajar dalam memabaca langsung tidak teliti. Ini disebabkan karena kalimat-kalimat dan perkataan yang diamati dengan mata dan pembelajar hanya berlangsung secara keseluruhan sehingga mengabaikan adanya hubungan antara huruf. Dengan begitu pembelajar didalam membaca hanya menerka atau mengira-ngirakan saja. 2). 
Dengan adanya perbedaan yang terdapat dalam kecakapan masing-masing anak terutama dalam mengadakan analisa menyebabkan dalam beberapa minggu saja ada perbedaan yang menyolok antara pembelajar sehingga sukar mengadakan hubungan di antara mereka secara klasikal.

Membahas masalah-masalah penelitian yang berhubungan dengan proses belajar di kelas menurut Gay dalam (Hardjodipuro:1997) menyarankan untuk menggunakan metode penelitian tindakan (action research) dan dalam penelitian ini guru merupakan bagian dari proses penelitian ini. Menurut (Hardjodipuro: 1997) action research adalah penelitian yang bersifat partisipatif dan kolaboratif yaitu penelitian yang dilakukan sendiri oleh yang berkepentingan yaitu peneliti dan diamati bersama-sama dengan rekannya, sedangkan menurut Isaac dalam Harjodiputro (1997) action research bertujuan untuk mengembangkan ketrampilan baru dan memecahkan masalah dengan melakukan penerapan langsung di kelas.

\section{Metode}

Jenis penelitian ini adalah Penelitian Tindakan Kelas (PTK). Peneliti menggunakan metode PTK ini karena dalam perencanaannya penelitian ini dilakukan dalam tiga siklus. Penelitian ini akan dilakukan pada siswa kelas satu tunarungu di SLB N Prof. Dr. Sri Soedewi Maschun Syofwan SH Jambi yang berjumlah empat orang. Terdiri dari dua orang laki-laki dan dua orang perempuan yang mana siswa-siswa tersebut mengalami keterlambatan membaca. Prosedur penelitian ini diantaranya perencanaan, pelaksanaan, observasi dan refleksi. Pada tahapan perencanaan kegiatan yang dilakukan adalah membuat rencana pelaksanaan pembelajaran, membuat skenario pelaksanaan tindakan, mempersiapkan sarana belajar yang mendukung metode SAS, membuat lembar observasi untuk melihat bagaimana kondisi belajar siswa, dan mendesain alat evaluasi. Dalam tahapan pelaksanaan tindakan kegiatan yang dilakukan adalah melaksanakan proses pembelajaran dengan menerapkan model pembelajaran menggunakan metode SAS sesuai dengan skenario pembelajaran yang telah dirancang. Selanjutnya tahapan observasi/evaluasi adalah melakukan observasi pada saat pelaksanaan tindakan dan evaluasi dilakukan pada setiap akhir siklus. Tahapan akhir adalah analisis dan refleksi dengan indikator keberhasilan tindakan adalah siswa membaca kalimat sederhana dengan baik, siswa membaca kata dengan baik, siswa membaca suku kata dengan baik, dan siswa membaca huruf dengan baik.

\section{Hasil Penelitian dan Pembahasan}

Hasil Observasi dan Evaluasi Siklus I

Kegiatan observasi dilakukan oleh observer yaitu tim peneliti dalam penelitian ini. Adapun variable yang diobservasi dengan menggunakan instrumen berupa lembar observasi yang mengukur kualitas tentang :

1). Kelancaran suara

2). Intonasi

3). Membaca kalimat

4). Membaca kata

5). Membaca suku kata 
6). Melafalkan huruf

Dengan menggunakan lembar observasi, hasil observasi siklus I Disajikan dalam tabel 1. pada siklus I siswa yang tuntas membaca baru mencapai 50\%, sedangkan belum tuntas membaca juga $50 \%$. Pada akhir pertemuan diberikan tes untuk mengukur hasil belajar siswa, hasil evaluasi belajar siswa pada siklus I adalah seperti disajikan pada tabel 2. dimana rata-rata nilai siswa adalah 45 .

Tabel 1: Hasil observasi ketuntasan belajar membaca siklus I dalam upaya meningkatkan kemampuan membaca permulaan dengan menggunakan metode SAS di SLB N prof. Dr. Sri Soedewi MSC SH Jambi.

\begin{tabular}{|c|c|c|c|c|c|c|c|c|c|c|c|c|}
\hline \multirow[t]{2}{*}{ No } & \multirow[t]{2}{*}{ Nama siswa } & \multicolumn{7}{|c|}{ Aspek yang diobservasi } & \multicolumn{4}{|c|}{ Ketuntasan } \\
\hline & & 1 & 2 & 3 & 4 & 5 & 6 & $\Sigma$ & TT & CT & $\mathrm{T}$ & ST \\
\hline \multicolumn{2}{|c|}{ 1. Syawal Saputra } & 1 & 1 & 1 & 1 & 1 & 1 & 6 & $\mathrm{~V}$ & - & - & - \\
\hline \multicolumn{2}{|c|}{ 2. Akromulyuda } & 2 & 3 & 2 & 2 & 2 & 2 & 13 & - & - & $\mathrm{V}$ & - \\
\hline \multicolumn{2}{|c|}{ 3. Asmawati } & 1 & 1 & 1 & 1 & 1 & 1 & 6 & $\overline{\mathrm{V}}$ & - & - & - \\
\hline \multicolumn{2}{|c|}{ 4. Septian } & 2 & 2 & 2 & 3 & 3 & 2 & 14 & - & - & $\mathrm{V}$ & - \\
\hline \multicolumn{2}{|r|}{$\Sigma$} & 6 & 7 & 6 & 7 & 7 & 6 & 39 & 2 & - & 2 & - \\
\hline \multicolumn{2}{|r|}{$\mu$} & & & & & & & & $50 \%$ & - & $50 \%$ & - \\
\hline \multicolumn{13}{|c|}{$\begin{array}{ll}\text { Catatan } & : 1=\text { kelancaran suara, } 2=\text { intonasi, } 3=\text { membaca kalimat, } 4=\text { membaca kata, } 5=\text { membaca suku kata, } 6=\text { melafalkan huruf } \\
\text { Bobot nilai } & : 1=\text { kurang, } 2=\text { cukup, } 3=\text { baik, } 4=\text { sangat baik } \\
\text { Rentang nilai } & : 1-6=\text { TT (tidak tuntas) } \\
& 7-12=\text { CT (cukup tuntas) } \\
& 13-18=\text { T (tuntas) } \\
19-24=\text { ST (sangat tuntas) }\end{array}$} \\
\hline
\end{tabular}

Tabel 2 : Hasil belajar siklus I untuk meningkatkan kemampuan membaca permulaan dengan menggunakan metode SAS di SLB N Prof. Dr. Sri Soedewi MSC SH Jambi.

\begin{tabular}{|c|c|c|c|c|c|c|c|c|}
\hline \multirow[t]{3}{*}{ No. } & \multirow{3}{*}{$\begin{array}{l}\text { Nama } \\
\text { siswa }\end{array}$} & \multicolumn{5}{|c|}{ Nomor soal/ bobot bacaan } & \multirow{3}{*}{$\begin{array}{l}\text { Jml } \\
\text { skor }\end{array}$} & \multirow{3}{*}{$\begin{array}{c}\% \\
\text { tercapai }\end{array}$} \\
\hline & & 1 & \multirow{2}{*}{2} & \multirow{2}{*}{$\begin{array}{c}3 \\
20\end{array}$} & \multirow{2}{*}{$\frac{4}{20}$} & \multirow{2}{*}{$\begin{array}{c}5 \\
20\end{array}$} & & \\
\hline & & 20 & & & & & & \\
\hline 1. & Syawal Saputra & 20 & - & - & 20 & - & 40 & 40 \\
\hline 2. & Akromulyuda & 20 & 10 & - & - & 20 & 50 & 50 \\
\hline 3. & Asmawati & - & 20 & - & 10 & - & 30 & 30 \\
\hline \multirow{2}{*}{\multicolumn{2}{|c|}{ 4. Septian }} & 20 & - & 20 & - & 20 & 60 & 60 \\
\hline & & & $1 \mathrm{a}$ & & & & 180 & 180 \\
\hline \multicolumn{7}{|c|}{ Rata-rata } & 45 & 45 \\
\hline \multicolumn{7}{|c|}{ persentase } & $45 \%$ & $45 \%$ \\
\hline
\end{tabular}

Hasil Observasi dan Evaluasi Siklus II

Kegiatan observasi dilakukan oleh observer yaitu teman sejawat dalam penelitian ini. Adapun 
variable yang diobservasi dengan menggunakan lembar observasi masih sama dengan yang digunakan pada siklus-I yang meliputi kualitas tentang :1) Kelancaran suara, 2) Intonasi, 3) Membaca kalimat, 4) Membaca kata, 5) Membaca suku kata, 6) Melafalkan huruf. Dengan menggunakan lembar observasi tervokus, hasil observasi siklus II Disajikan dalam tabel 3. Disini dapat dilihat bahwa siswa yang cukup tuntas membaca $50 \%$, tuntas $25 \%$, dan sangat tuntas $25 \%$.

Untuk mengukur keberhasilan pembelajaran, pada akhir pertemuan diberikan tes untuk mengukur hasil belajar siswa sebagai tampilan unjuk kerja pada siklus II. hasil evaluasi belajar siswa pada siklus II adalah seperti disajikan pada tabel 4. nilai rata-rata siswa mencapai 60.

Tabel 3 : Hasil observasi ketuntasan belajar membaca siklus II dalam upaya Meningkatkan kemampuan membaca permulaan dengan menggunakan metode SAS Sri Soedewi MSC SH Jambi.

\begin{tabular}{lcccccccccccc}
\hline No Nama siswa & \multicolumn{1}{c}{ Aspek yang diobservasi } & \multicolumn{4}{c}{ Ketuntasan } \\
\cline { 2 - 12 } & 1 & 2 & 3 & 4 & 5 & 6 & $\Sigma$ & TT & CT & T & ST \\
\hline 1. Syawal Saputra & 2 & 2 & 2 & 2 & 2 & 2 & 12 & - & $\mathrm{V}$ & - & - \\
\hline 2. Akromulyuda & 2 & 3 & 3 & 3 & 3 & 3 & 17 & - & - & $\mathrm{V}$ & - \\
\hline 3. Asmawati & 1 & 2 & 2 & 1 & 2 & 3 & 11 & - & $\mathrm{V}$ & - & - \\
\hline 4. Septian & 3 & 3 & 3 & 4 & 3 & 4 & 20 & - & - & - & $\mathrm{V}$ \\
\hline \multicolumn{1}{c}{$\Sigma$} & 9 & 11 & 10 & 10 & 10 & 12 & & - & 2 & 1 & 1 \\
\hline$\mu$ & & & & & & & & & $50 \%$ & $25 \%$ & $25 \%$
\end{tabular}

$\begin{array}{ll}\text { Catatan } & : 1=\text { kelancaran suara, } 2=\text { intonasi, } 3=\text { membaca kalimat } 4=\text { membaca kata, } 5=\text { membaca suku kata, } 6=\text { melafalkan huruf } \\ \text { Bobot nilai } & : 1=\text { kurang, } 2=\text { cukup, } 3=\text { baik, } 4=\text { sangat baik } \\ \text { Rentang nilai } & : 1-6=\text { TT (tidak tuntas) } \\ & 7-12=\text { CT (cukup tuntas) } \\ 13-18=\text { T (tuntas) } \\ 19-24=\text { ST (sangat tuntas) }\end{array}$

Tabel 4 : Hasil belajar siklus II untuk meningkatkan kemampuan membaca permulaan dengan menggunakan metode SAS di SLB N Prof. Dr. Sri Soedewi MSC SH Jambi.

\begin{tabular}{|c|c|c|c|c|c|c|c|c|c|}
\hline & \multirow{3}{*}{$\begin{array}{l}\text { Nama } \\
\text { siswa }\end{array}$} & \multicolumn{6}{|c|}{ Nomor soal/ bobot bacaan } & \multirow{3}{*}{$\begin{array}{l}\text { Jml } \\
\text { skor }\end{array}$} & \multirow{3}{*}{$\begin{array}{c}\% \\
\text { tercapai }\end{array}$} \\
\hline & & \multicolumn{2}{|r|}{1} & \multirow{2}{*}{2} & \multirow{2}{*}{$\frac{3}{20}$} & \multirow{2}{*}{$\frac{4}{20}$} & \multirow{2}{*}{$\begin{array}{c}5 \\
20\end{array}$} & & \\
\hline & & & 20 & & & & & & \\
\hline 1. & Syawal Saputra & & 20 & - & 10 & 20 & - & 50 & 50 \\
\hline 2. & Akromulyuda & & 20 & 20 & - & - & 20 & 60 & 60 \\
\hline 3. & Asmawati & & 20 & 20 & - & 20 & - & 60 & 60 \\
\hline \multirow{2}{*}{\multicolumn{2}{|c|}{ 4. Septian }} & & 20 & - & 20 & 10 & 20 & 70 & 70 \\
\hline & & & $\mathrm{u} \mathrm{m}$ & & & & & 240 & 240 \\
\hline \multicolumn{8}{|c|}{ Rata-rata } & 60 & 60 \\
\hline \multicolumn{8}{|c|}{ persentase } & $60 \%$ & $60 \%$ \\
\hline
\end{tabular}

Hasil Observasi dan Evaluasi siklus III

Kegiatan observasi ini dilakukan oleh observer yaitu teman sejawat peneliti dalam penelitian 
ini. Variabel yang diobservasi dengan menggunakan instrument berupa lembar observasi yang mengukur kualitas tentang : 1) Kelancaran suara, 2) Intonasi, 3). Membaca kalimat, 4) Membaca kata 5) Membaca suku kata, 6) Melafalkan huruf.

Dengan menggunakan lembar observasi yang telah disiapkan, maka hasil observasi siklus III disajikan pada table 5. pada siklus III ketuntasan membaca meningkat yaitu tuntas membaca sebanyak $75 \%$, sedangkan siswa yang mencapai sangat tuntas membaca sebanyak $25 \%$. Hasil evaluasi belajar siswa pada siklus III seperti disajikan pada tabel 6 . hasil belajar siswa mencapai nilai rata-rata 75.

Tabel 5: Hasil observasi ketuntasan belajar membaca siklus III dalam upaya meningkatkan kemampuan membaca permulaan dengan menggunakan metode SAS di SLB N Prof. Dr. Sri Soedewi MSC Jambi.

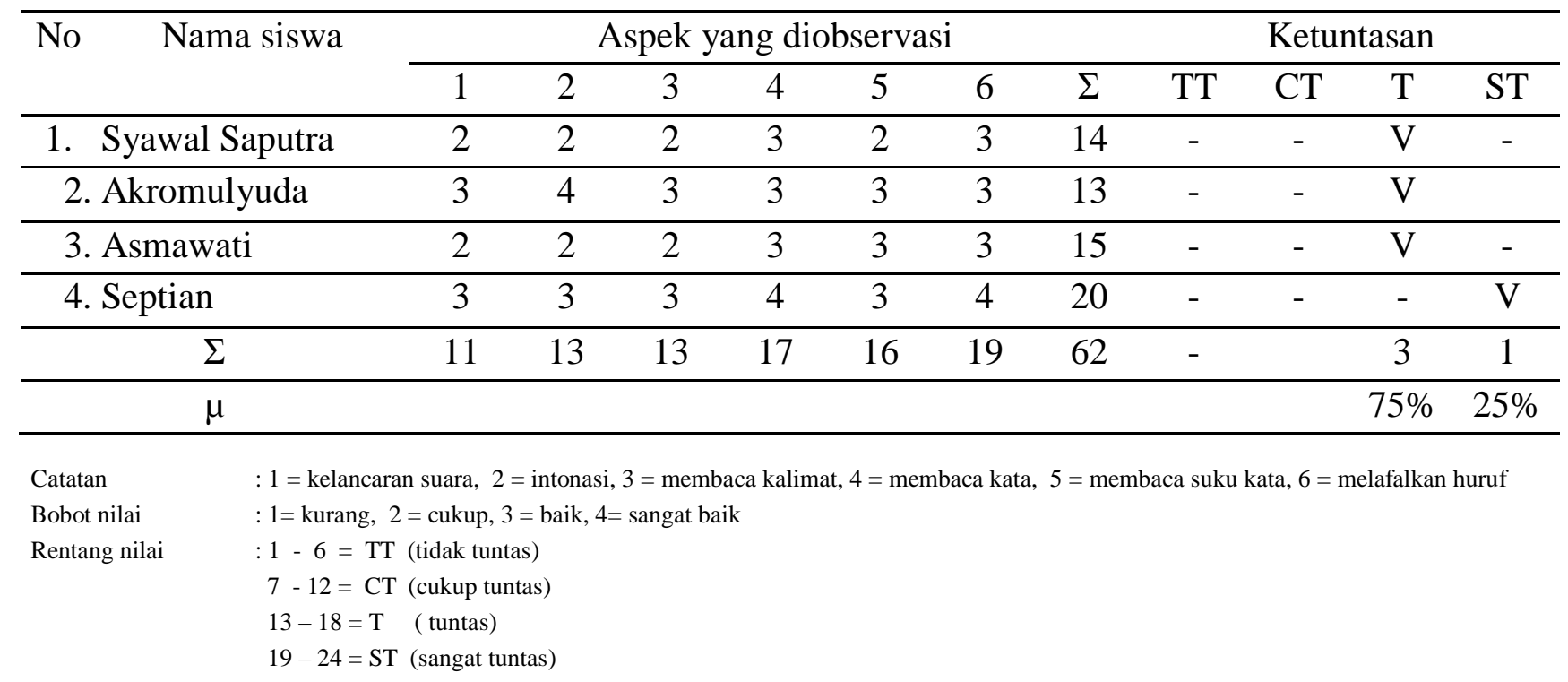

Untuk mengetahui materi yang dikuasai siswa, pada akhir pertemuan diberikan tes untuk mengukur hasil belajar sebagai tampilan unjuk kerja pada siklus III. hasil evaluasi belajar siswa pada siklus III adalah seperti disajikan pada tabel berikut.

Tabel 6 : Hasil belajar siklus III untuk meningkatkan kemampuan membaca Permulaan dengan menggunakan metode SAS di SLB N Prof. Dr. Sri Soedewi MSC Jambi.

\begin{tabular}{|c|c|c|c|c|c|c|c|c|}
\hline \multirow[t]{3}{*}{ No. } & \multirow{3}{*}{$\begin{array}{l}\text { Nama } \\
\text { siswa }\end{array}$} & \multicolumn{5}{|c|}{ Nomor soal/ bobot bacaan } & \multirow{3}{*}{$\begin{array}{l}\text { Jml } \\
\text { skor }\end{array}$} & \multirow{3}{*}{$\begin{array}{c}\% \\
\text { tercapai }\end{array}$} \\
\hline & & 1 & 2 & 3 & 4 & 5 & & \\
\hline & & 20 & 20 & 20 & 20 & 20 & & \\
\hline 1 & Syawal Saputra & 20 & 20 & 10 & 20 & - & 70 & 70 \\
\hline 2 & Akromulyuda & 20 & 20 & 20 & - & 20 & 80 & 80 \\
\hline 3 & Asmawati & 20 & 20 & 10 & 20 & - & 70 & 70 \\
\hline \multirow[t]{2}{*}{4} & Septian & 20 & 10 & 20 & 10 & 20 & 80 & 80 \\
\hline & & $\mathrm{J} \quad \mathrm{u}$ & $1 \mathrm{a}$ & & & & 300 & 300 \\
\hline
\end{tabular}




\begin{tabular}{ccc}
\hline Rata-rata & 75 & 75 \\
\hline persentase & $75 \%$ & $75 \%$ \\
\hline
\end{tabular}

Hasil penelitian dengan menggunakan pola 3 (tiga) siklus. Ternyata dapat menguji hipotesis tindakan yang diajukan dalam penelitian ini. Berdasarkan kerangka teoritis yang disajikan pada Bab-I di muka, dalam penelitian ini diajukan hipotesis tindakan yaitu "Jika Penggunaan metode SAS, maka hasil belajar membaca permulaan siswa akan meningkat minimal rerata nilai 70".

Kemudian yang menjadi kriteria keberhasilan dalam penelitian tindakan ini sebagaimana telah dikemukakan pada bab III metode penelitin adalah; jika variabel ketuntasan belajar yang diukur oleh lembaran observasi mencapai nilai rerata "tuntas" (lebih besar dari skor 13), dan variabel hasil belajar yang diukur dengan lembaran tes mencapai nilai rerata 75 dalam skala $10-100$, yang berarti tingkat penguasan kompetensi minimal $70 \%$ pada tingkat " tinggi “.

Untuk melihat lebih jelas keterhubungan hasil penelitian pada masing-masing siklus dengan kriteria keberhasilan yang telah ditetapkan, berikut tabel 4.7 disajikan rekaman data perkembangan hasil observasi dan hasil belajar pada setiap siklus sebagai berikut :

Tabel 7 : Rekapitulasi hasil PTK penggunaan metode SAS dalam membaca permulaan bagi siswa kelas satu Tunarungu di SLB N Sri Soedewi mschun Syofwan SH Jambi

\begin{tabular}{llcccc}
\hline No & \multicolumn{1}{c}{$\begin{array}{c}\text { Nama } \\
\end{array}$} & \multicolumn{2}{c}{ Sekolah } & Variabel & \multicolumn{3}{c}{ Hasil PTK } \\
\cline { 3 - 5 } & Penelitian & Siklus-I & Siklus-II & Siklus-III \\
\hline 1. & SLB N Prof. Dr. & Ketuntasan belajar & $50 \%$ & $75 \%$ & $100 \%$ \\
& $\begin{array}{l}\text { Sri } \\
\text { MSC jambi. }\end{array}$ & Hasil belajar & 45 & 60 & 75 \\
\cline { 3 - 5 } & & & & & \\
\hline
\end{tabular}

Dari tabel 7 diatas, kedua variabel yang diukur secara keseluruhan menunjukkan adanya peningkatan pada setiap siklus. Pada akhir siklus - III seluruh target kriteria dapat dipenuhi. Oleh karenanya hipotesis yang diajukan dapat diterima.

Membaca merupakan hal yang sangat penting dalam kehidupan. Karena membaca bukanlah sekedar bisa untuk membaca saja, melainkan untuk kepenting perkembangan seorang anak kecil menjadi manusia dewasa yang mampu menggunakan kepandaiannya membaca untuk menambah pengetahuan dan mengembangkan kepribadiannya lebih lanjut. Membaca juga diartikan sebagai suatu metode yang dipakai untuk berkomunikasi dengan diri sendiri, yaitu mengkomunikasikan makna yang terkandung atau tersirat dalam lambang-lambang tertulis. Membaca adalah menyuarakan lambanglambang tertulis atau mengubah simbol-simbol tertulis kedalam bentuk lisan dengan lafal dan intonasi yang wajar.

Membaca permulaan merupakan membaca awal yang diberikan kepada siswa di kelas satu dan kelas dua sebagai dasar untuk pelajaran membaca selanjutnya. Membaca permulaan mengutamakan pengajaran huruf dan rangkaiannya, serta melancarkan teknik membaca. Siswa masih bisa dilatih dan dikembangkan kemampuannya, dan diharapkan dengan pengajaran membaca permulaan, siswa dapat mengikuti pengajaran membaca lanjutan, sehingga siswa bisa meneruskan pendidikannya ke jenjang 
berikutnya.

Metode SAS mula-mula kepada siswa diperkenalkan beberapa kalimat. setelah mereka dapat membacanya, salah satu kalimat diambil untuk diuraikan menjadi kata, kemudian kata diuraikan menjadi suku kata, suku kata diuraikan menjadi huruf-huruf, dan akhirnya kembali ke kalimat. Dengan penguraian itu siswa mengenal dan membaca huruf. Dengan pengenalan kalimat, kata, suku kata, huruf,dan kalimat siswa diharapkan dapat membaca kata-kata dan kalimat yang mengandung hurufhuruf tersebut. Pembelajaran dengan membaca beberapa kalimat, sehingga pembelajaran dapat membedakan kalimat yang satu tidak sama dengan kalimat yang lain. Hal ini dilaksanakan dengan analisa. Dengan jalan analisa ini pembelajaran dapat membedakan juga antara kata yang satu dengan kata yang lain.

\section{Kesimpulan}

Berdasarkan hasil penelitian tindakan kelas dengan menggunaan metode SAS dapat meningkatkan kemampuan membaca siswa kelas I SLB Negeri Prof. Dr. Sri Soedewi Maschun SyowanKota Jambi, dapat disimpulkan sebagai berikut: Setelah penggunaan metode SAS dalam membaca permulaan pada proses pembelajaran Siklus-I, belum dapat meningkatkan ketuntasan dan hasil belajar siswa. Adapun indikator yang dapat disimak antara lain : (a) Proses pembelajaran yang diukur melalui lembar observasi baru mencapai 50\% siswa yang dapat mencapai kategori tuntas, (b) dampak lanjutannya adalah nilai rerata hasil belajar pada siklus -I baru mencapai nilai 45 , yang berarti bahwa rerata tingkat penguasaan kompetensi siswa pada siklus I baru mencapai $45 \%$, bila dihubungkan dengan kriteria keberhasilan, belum memenuhi kriteria yang ditetapkan. Terdapat peningkatan ketuntasan belajar dan hasil belajar setelah menggunakan metode SAS pada siklus- II. Ketuntasan belajar menjadi $75 \%$ dan hasil belajar rerata 60 yang berarti kompetensi yang dicapai adalah $60 \%$. Terbukti terjadi peningkatan yang signifikan, ketuntasan belajar dan hasil belajar siswa setelah menggunakan metode SAS pada siklus-III. Hal ini mengandung makna bahwa PTK dapat dinyatakan" berhasil". Keberhasilan ini ditunjukkan oleh indikator sebagai berikut : (a) Siswa berhasil mencapai kategori tuntas belajar (100\%), bahkan 38\% termasuk kategori " sangat tuntas". (b) Hasil belajar siswa mencapai nilai rerata 75 , melebihi kriteria yang ditetapkan yaitu rerata 70 .

\section{Daftar Rujukan}

Akhadiah S, (1991). Bahasa Indonesia. Jakarta; Depdikbud

Arsyad, (1996). Media Pembelajaran. Jakarta; Raja Grafindo Persada

Diknas. (1996). Metodik khusus pengajaran Bahasa Indonesia di SD. Jakarta; Depdikbud.

Diknas. (1998). Petunjuk Pengajaran Membaca dan menulis di kelas I, II di Sekolah Dasar. Jakarta; Depdikbud.

Effendi M (2006). Pengantar Psikopedagogik Anak Berkelainan, Jakarta : Bumi Aksara.

Jodian dan Asrial. (2010). Model Pembelajaran Sains. FKIP Unja

Ritawati. (1996). Bahan Ajar pendidikan Bahasa Indonesia di Kelas rendah SD. Padang ; IKIP Padang. 
Kartadinata S (1999), Bimbingan Di Sekolah Dasar, Bandung : Departemen Pendidikan Dan Kebudayaan : Direktorat Jendral Pendidikan Tinggi

Sadjaah Edja. (1995). Bina Persepsi bunyi dan Irama. Jakarta; Depdikbud.

Somad Permanarian dan Tati H. (1996). Ortopedagogik Anak Tunarungu. Jakarta; Depdikbud.

Sudjana, N. ( 2000). Dasar-dasar Proses Belajar Mengajar, Bandung : Sinar Baru Algesindo

Suharsimi, A (2006). Penelitian tindakan Kelas, Jakarta : Bumi Aksara

Sumantri, T S (2006). Psikologi Anak Luar Biasa, Bandung Refika Aditama

Yusuf, M. (2003) Pendidikan bagi Anak dengan Problema Belajar, Solo : Tiga Serangkai Pustaka Mandiri

Winkel, WS (1996). Psikologi Pengajaran, Jakarta : Grasindo

Herman, J. (1994). Penelitian pendidikan Bahasa dan Sastra. Surakarta;Sebelas Maret University press.

Rejana, Imam (1991). Pendidikan Bahasa Indonesia 2. Jakarta; Depdikbud. 